OPEN ACCESS

Edited by:

Maik Gollasch

Charité Universitätsmedizin Berlin,

Germany

Reviewed by:

Withrow Gil Wier,

University of Maryland, Baltimore,

USA

Jonathan $H$. Jaggar,

University of Tennessee Health

Science Center, USA

Fabio Fusi,

Universitá degli Studi di Siena, Italy

*Correspondence: George C. Wellman

gwellman@uvm.edu

Specialty section: This article was submitted to

Vascular Physiology,

a section of the journal

Frontiers in Physiology

Received: 05 December 2016 Accepted: 23 March 2017

Published: 07 April 2017

Citation:

Wang $F$, Koide $M$ and Wellman GC

(2017) Nifedipine Inhibition of

High-Voltage Activated Calcium

Channel Currents in Cerebral Artery

Myocytes Is Influenced by Extracellular

Divalent Cations.

Front. Physiol. 8:210

doi: 10.3389/fphys.2017.00210

\section{Nifedipine Inhibition of High-Voltage Activated Calcium Channel Currents in Cerebral Artery Myocytes Is Influenced by Extracellular Divalent Cations}

\author{
Fei Wang ${ }^{1,2}$, Masayo Koide ${ }^{1}$ and George C. Wellman ${ }^{1 *}$ \\ ${ }^{1}$ Department of Pharmacology, University of Vermont Larner College of Medicine, Burlington, VT, USA, ${ }^{2}$ Second Department \\ of Neurosurgery, First Affiliated Hospital of Kunming Medical University, Kunming, China
}

Voltage-dependent calcium channels (VDCCs) play an essential role in regulating cerebral artery diameter and it is widely appreciated that the L-type VDCC, Cav1.2, encoded by the CACNA1C gene, is a principal $\mathrm{Ca}^{2+}$ entry pathway in vascular myocytes. However, electrophysiological studies using $10 \mathrm{mM}$ extracellular barium $\left(\left[\mathrm{Ba}^{2+}\right]_{0}\right)$ as a charge carrier have shown that $\sim 20 \%$ of VDCC currents in cerebral artery myocytes are insensitive to 1,4-dihydropyridine (1,4-DHP) L-type VDDC inhibitors such as nifedipine. Here, we investigated the hypothesis that the concentration of extracellular divalent cations can influence nifedipine inhibition of VDCC currents. Whole-cell VDCC membrane currents were obtained from freshly isolated rat cerebral artery myocytes in extracellular solutions containing $\mathrm{Ba}^{2+}$ and/or $\mathrm{Ca}^{2+}$. In the absence of $\left[\mathrm{Ca}^{2+}\right]_{0}$, both nifedipine-sensitive and -insensitive calcium currents were observed in $10 \mathrm{mM}\left[\mathrm{Ba}^{2+}\right]_{0}$. However, VDCC currents were abolished by nifedipine when using a combination of $10 \mathrm{mM}\left[\mathrm{Ba}^{2+}\right]_{0}$ and $100 \mu \mathrm{M}\left[\mathrm{Ca}^{2+}\right]_{0}$. VDCC currents were also completely inhibited by nifedipine in either $2 \mathrm{mM}\left[\mathrm{Ba}^{2+}\right]_{0}$ or $\left.2 \mathrm{mM}^{\left[\mathrm{Ca}^{2+}\right.}\right]_{0}$. The biophysical characteristics of all recorded VDCC currents were consistent with properties of a high-voltage activated VDCC, such as Cav1.2. Further, VDCC currents recorded in $10 \mathrm{mM}\left[\mathrm{Ba}^{2+}\right]_{0} \pm 100 \mu \mathrm{M}$ $\left[\mathrm{Ca}^{2+}\right]_{0}$ or $2 \mathrm{mM}\left[\mathrm{Ba}^{2+}\right]_{0}$ exhibited similar sensitivity to the benzothiazepine L-type VDCC blocker, diltiazem, with complete current inhibition at $100 \mu \mathrm{M}$. These data suggest that nifedipine inhibition is influenced by both $\mathrm{Ca}^{2+}$ binding to an external site(s) on these channels and surface charge effects related to extracellular divalent cations. In sum, this work demonstrates that the extracellular environment can profoundly impact VDCC current measurements.

Keywords: cerebral artery, vascular smooth muscle, nifedipine, patch clamp, voltage-dependent calcium channels

\section{INTRODUCTION}

Members of the voltage-dependent calcium channel (VDCC) family are involved in a multitude of physiological processes throughout the body. The classification of VDCC subtypes is based on the amino acid sequence of the channels' pore-forming alpha1-subunit, which principally determines gating properties such as the voltage dependence of channel activation/inactivation 
and sensitivity to pharmacological agents (Catterall et al., 2003; Alexander et al., 2015). It is widely appreciated that the L-type VDCC, $\mathrm{Ca}_{V} 1.2$, encoded by the gene CACNA1C, represents an important extracellular calcium $\left(\left[\mathrm{Ca}^{2+}\right]_{0}\right)$ entry pathway involved in the regulation of bulk cytosolic $\mathrm{Ca}^{2+}$ and contraction of vascular smooth muscle, including cerebral artery myocytes (Moosmang et al., 2003; Nystoriak et al., 2009). For example, dynamic Cav1.2 gating in response to pressuredependent changes in smooth muscle membrane potential plays a central role in modulating cerebral artery diameter and the autoregulation of cerebral blood flow (Knot and Nelson, 1998; Davis and Hill, 1999; Nystoriak et al., 2011). Further, 1,4dihydropyridines (1,4-DHPs), a class of compounds including nifedipine and nimodipine, that are selective inhibitors of Ltype VDCCs have been used extensively in the treatment of a wide range of cardiovascular disorders, including protection against cerebral vasospasm following subarachnoid hemorrhage (Wellman, 2006; Young et al., 2015).

Radioligand binding assays used to examine interactions between 1,4-DHPs and Cav1.2 have shown the binding of these two entities to be extremely dependent on the nature and concentration of divalent cations present (Ebata et al., 1990; Yamada et al., 1990; Hille, 2001; Nakajima et al., 2002). Yamada et al., using porcine coronary artery preparations, found that $\mathrm{Ca}^{2+}$ is required for high affinity binding of 1,4-DHPs to $\mathrm{Ca}_{V} 1.2$, whereas $\mathrm{Ba}^{2+}$ had the opposite effect, i.e., inhibition of ligand/channel binding. Additional evidence indicates that it is a $\mathrm{Ca}^{2+}$ binding site on the extracellular surface of $\mathrm{Cav}_{V} 1.2$ that promotes high affinity 1,4-DHP binding (Ebata et al., 1990). However, because $\mathrm{Ba}^{2+}$ permeates several types of VDCCs more effectively than $\mathrm{Ca}^{2+}, \mathrm{Ba}^{2+}$ has commonly been used as a charge carrier during electrophysiological recordings to enhance the amplitude of VDCC membrane currents in cells having low channel number.

Using $10 \mathrm{mM}$ extracellular barium $\left(\left[\mathrm{Ba}^{2+}\right]_{\mathrm{o}}\right)$ as a charge carrier, several groups have shown that $\sim 20 \%$ of VDCC currents in cerebral artery myocytes are insensitive to high concentrations $(1 \mu \mathrm{M})$ of nifedipine (Nikitina et al., 2007; Kuo et al., 2010; Abd El-Rahman et al., 2013; Harraz and Welsh, 2013a). The identity of these currents, often referred to as nifedipineinsensitive calcium currents (NICCs), is controversial and several VDCCs other than Cav1.2 have been implicated. The goal of the present study was to examine the influence of $\left[\mathrm{Ba}^{2+}\right]_{0}$ and $\left[\mathrm{Ca}^{2+}\right]_{0}$ on the efficacy of the 1,4-DHP, nifedipine, to inhibit VDCC membrane currents in freshly isolated rat cerebral artery myocytes. Our data indicate that the use of $\mathrm{Ba}^{2+}$ and/or $\mathrm{Ca}^{2+}$ as charge carriers not only influences VDCC current density, but also impacts the ability of nifedipine to inhibit these currents.

\section{MATERIALS AND METHODS}

\section{Animal Procedures}

All procedures were conducted in accordance with the Guide for the Care and Use of Laboratory Animals (eighth edition, 2011) and followed protocols approved by the Institutional Animal Care and Use Committee at the University of Vermont.
Male Sprague-Dawley rats (300-350g) were euthanized by decapitation under deep anesthesia with pentobarbital $(60 \mathrm{mg} / \mathrm{kg})$. Brains were removed from the skull and placed in cold $\left(\sim 3^{\circ} \mathrm{C}\right)$ artificial cerebrospinal fluid $(\mathrm{aCSF})$ of the following composition: $125 \mathrm{mM} \mathrm{NaCl}, 3 \mathrm{mM} \mathrm{KCl}, 18 \mathrm{mM}$ $\mathrm{NaHCO}_{3}, 1.25 \mathrm{mM} \mathrm{NaH}_{2} \mathrm{PO}_{4}, 1 \mathrm{mM} \mathrm{MgCl} 2,2 \mathrm{mM} \mathrm{CaCl}_{2}$, and $5 \mathrm{mM}$ glucose, $\mathrm{pH}$ 7.30. Posterior cerebral arteries (PCAs) were dissected from the brain and arachnoid membrane, then kept in cold aCSF prior to cell isolation.

\section{Isolation of Cerebral Artery Myocytes}

Cerebral artery myocytes were enzymatically dissociated from PCAs as previously described (Koide et al., 2007). Briefly, arteries were first incubated in isolation solution containing $0.3 \mathrm{mg} / \mathrm{ml}$ papain and $0.7 \mathrm{mg} / \mathrm{ml}$ dithioerythritol at $37^{\circ} \mathrm{C}$ for $17 \mathrm{~min}$. PCA segments were then transferred to isolation solution containing $0.7 \mathrm{mg} / \mathrm{ml}$ type $\mathrm{F}$ collagenase and $0.3 \mathrm{mg} / \mathrm{ml}$ type $\mathrm{H}$ collagenase and incubated at $37^{\circ} \mathrm{C}$ for an additional $15 \mathrm{~min}$. After the second incubation period, arteries were washed three times with cold isolation solution and triturated gently using a fire-polished Pasteur pipette to disperse individual myocytes. Cells were kept in isolation solution on ice and used for study within $6 \mathrm{~h}$. The isolation solution contained: $55 \mathrm{mM} \mathrm{NaCl}, 80 \mathrm{mM}$ sodium glutamate, $5.6 \mathrm{mM} \mathrm{KCl}, 10 \mathrm{mM}$ HEPES, $2 \mathrm{mM} \mathrm{MgCl}_{2}, 100 \mu \mathrm{M}$ $\mathrm{CaCl}_{2}$, and $10 \mathrm{mM}$ glucose ( $\mathrm{pH} 7.30$ ).

\section{Measurement of VDCC Membrane Currents}

The conventional whole cell configuration of the patch clamp technique was utilized to measure whole cell VDCC membrane currents of cerebral artery myocytes using an Axopatch 200B amplifier (Molecular Devices Corp., Sunnyvale, CA). The pipette solution contained $130 \mathrm{mM} \mathrm{CsCl}, 10 \mathrm{mM}$ EGTA, $10 \mathrm{mM}$ HEPES, $2 \mathrm{mM}$ ATP, $0.5 \mathrm{mM}$ GTP, $5 \mathrm{mM}$ phosphocreatine, and $10 \mathrm{mM}$ glucose with $\mathrm{pH}$ adjusted to 7.20 with $1 \mathrm{M} \mathrm{CsOH}$. Patch pipettes had resistances between 3 and $5 \mathrm{M} \Omega$ when filled with pipette solution. The extracellular solution contained $125 \mathrm{mM} \mathrm{NaCl}$, $10 \mathrm{mM}$ HEPES, $10 \mathrm{mM}$ glucose, $1 \mathrm{mM} \mathrm{MgCl}_{2}, 5 \mathrm{mM} \mathrm{KCl}$ and charge carrier $\left(10 \mathrm{mM} \mathrm{Ba}^{2+}\right.$ or $10 \mathrm{mM} \mathrm{Ba}^{2+}$ plus $100 \mu \mathrm{M} \mathrm{Ca}^{2+}$ or $2 \mathrm{mM} \mathrm{Ba}^{2+}$ or $2 \mathrm{mM} \mathrm{Ca}^{2+}$ ) with $\mathrm{pH}$ adjusted to 7.40 with $1 \mathrm{M}$ $\mathrm{NaOH}$. Osmolarity of intracellular and extracellular solutions were measured using a VAPRO vapor pressure osmometer (Wescor Inc.) and were $295 \pm 5 \mathrm{mOsm}$. Pipette offset, whole-cell capacitance, and series resistance were compensated manually. Cell capacitance of myocytes were $13.78 \pm 0.31,14.14 \pm$ $0.29,13.21 \pm 0.27$, and $13.68 \pm 0.34 \mathrm{pF}$ in $10 \mathrm{mM}\left[\mathrm{Ba}^{2+}\right]_{\mathrm{o}}$, $10 \mathrm{mM}\left[\mathrm{Ba}^{2+}\right]_{\mathrm{o}}$ plus $100 \mu \mathrm{M}\left[\mathrm{Ca}^{2+}\right]_{\mathrm{o}}, 2 \mathrm{mM}\left[\mathrm{Ba}^{2+}\right]_{\mathrm{o}}$, and $2 \mathrm{mM}$ $\left[\mathrm{Ca}^{2+}\right]_{0}$, respectively, and not significantly different between groups. Series resistance measurements were $11.97 \pm 1.31,12.86$ $\pm 1.98,10.19 \pm 1.59$, and $11.77 \pm 0.94 \mathrm{M} \Omega$ in $10 \mathrm{mM}\left[\mathrm{Ba}^{2+}\right]_{\mathrm{o}}$, $10 \mathrm{mM}\left[\mathrm{Ba}^{2+}\right]_{o}$ plus $100 \mu \mathrm{M}\left[\mathrm{Ca}^{2+}\right]_{o}, 2 \mathrm{mM}\left[\mathrm{Ba}^{2+}\right]_{o}$, and $2 \mathrm{mM}$ $\left[\mathrm{Ca}^{2+}\right]_{\mathrm{o}}$, respectively, and were also not significantly different between groups.

Myocytes were voltage clamped at a holding potential of $-80 \mathrm{mV}$ for $\sim 5 \mathrm{~min}$ prior to the start of an experimental series. During this initial period, single depolarizing steps to $+10 \mathrm{mV}$ were applied to cells to ensure current amplitudes were stable 
before starting experimental protocols. Voltage protocols were driven and data were acquired using pCLAMP 9.2 software (Molecular Devices Corp., Sunnyvale, CA). Current traces were filtered at $1 \mathrm{kHz}$ with a low-pass filter, subjected to $\mathrm{P} / 4$ leak subtraction and digitized at $5 \mathrm{kHz}$. Current-voltage relationships were obtained in response to a series of successive $10 \mathrm{mV}$ depolarizing voltage steps ( $800 \mathrm{~ms}$ in duration) from the holding potential of $-80 \mathrm{mV}$ to $+50 \mathrm{mV}$ at $5 \mathrm{~s}$ intervals. Steady-state activation curves were also obtained using this protocol by measuring currents at the end of the $800 \mathrm{~ms}$ voltage step and dividing these measurements by peak currents obtained for each cell to obtain $\mathrm{I} / \mathrm{I}_{\max }$. These values were then plotted against test voltage to calculate the half-activation voltage $\left(\mathrm{V}_{0.5 \mathrm{act}}\right)$. In some cells, a voltage ramp protocol was used that applied a continuous depolarization from -80 to $+50 \mathrm{mV}$ over the course of $300 \mathrm{~ms}$. Concentration-response relationships for the inhibition of VDCC currents by nifedipine and diltiazem were obtained in separate cells where currents were evoked by a single $200 \mathrm{~ms}$ duration voltage step from a holding potential of -80 to $+10 \mathrm{mV}$. Solution changes were made via perfusion of the recording chamber (chamber volume: $\sim 500 \mu \mathrm{l}$ ) for $10 \mathrm{~min}$ at a flow rate of $\sim 1.9 \mathrm{ml} / \mathrm{min}$. Steady-state inactivation curves were obtained using a double-step voltage protocol that applied a $5 \mathrm{~s}$ conditioning pulse step from -80 to $+40 \mathrm{mV}(10 \mathrm{mV}$ increments) followed by a return to $-80 \mathrm{mV}$ for $15 \mathrm{~ms}$ and then $150 \mathrm{~ms}$ test voltage step to $10 \mathrm{mV}$. All current recordings were done at room temperature $\left(20-22^{\circ} \mathrm{C}\right)$.

\section{Drugs and Reagents}

All chemicals and reagents including nifedipine and diltiazem were purchased from Sigma-Aldrich (St. Louis, MO) with the exception of papain, which was purchased from Worthington Biochemical Corp. (Lakewood, NJ).

\section{Data Analysis and Statistics}

Data were analyzed using Clampfit 9.2 software (Molecular Devices Corp., Sunnyvale, CA) as current density by dividing current amplitude by cell capacitance and are expressed as mean \pm standard error of the mean (SEM). The number of cells in each dataset is denoted as " $n$ " followed by the number of rats from which cells were obtained. The paired $t$ test was used for paired-sample analysis. For multiple group comparisons, data were initially evaluated by one-way ANOVA, with a $p<0.05$ considered statistically significant followed by paired comparisons between two groups using Tukey's multiple comparisons post-test. The voltages for half-maximal activation $\left(\mathrm{V}_{0.5 \mathrm{act}}\right)$ and half-maximal inactivation $\left(\mathrm{V}_{0.5 \text { inact }}\right)$ were obtained from Boltzman fit of steady-state activation and inactivation curves. Concentration-inhibition curves for nifedipine or diltiazem were calculated after normalization to currents in the absence of drug and fitted to the following equation: $y=\mathrm{I}_{\max } /\left\{1+\left([\mathrm{drug}] / \mathrm{K}_{i}\right) \mathrm{nH}\right\}+\mathrm{r}$, where $\mathrm{I}_{\max }$, [drug], $\mathrm{K}_{i}, \mathrm{nH}$, and $\mathrm{r}$ represent the maximum currents density, concentration of drug, binding affinity of drug, Hill coefficient, and drug resistant currents, respectively (Ebata et al., 1990). The IC $_{50}$ of a drug was determined from concentration-inhibition curves.

\section{RESULTS}

\section{Nifedipine Inhibition of VDCC Currents Using $10 \mathrm{mM}\left[\mathrm{Ba}^{2+}\right]_{\mathrm{o}}$ as a Charge Carrier}

Using $10 \mathrm{mM}\left[\mathrm{Ba}^{2+}\right]_{0}$ as a charge carrier, VDCC currents were elicited in rat cerebral artery myocytes by a series of $10 \mathrm{mV}$ depolarizing steps from a holding potential $-80 \mathrm{mV}$. In nominally $\mathrm{Ca}^{2+}$ free $10 \mathrm{mM} \mathrm{Ba}{ }^{2+}$ bath solution, a maximum VDCC current density of $-7.30 \pm 0.35 \mathrm{pA} / \mathrm{pF}(n=8$ cells from four animals) was observed at $+10 \mathrm{mV}$ (Figures 1A,C). In the presence of nifedipine $(1 \mu \mathrm{M})$, VDCC currents were reduced, but not abolished (Figures $1 \mathrm{~B}, \mathrm{C}$ ). At $+10 \mathrm{mV}$, the nifedipine-insensitive current density $(-1.62 \pm 0.48 \mathrm{pA} / \mathrm{pF})$ was $\sim 22 \%$ of total VDCC current density measured in these cells. To examine the impact of $\left[\mathrm{Ca}^{2+}\right]_{0}$ on VDCC currents when $10 \mathrm{mM}\left[\mathrm{Ba}^{2+}\right]_{0}$ is used as the primary charge carrier, the above voltage-step protocol was repeated using myocytes bathed in a combination of $10 \mathrm{mM}\left[\mathrm{Ba}^{2+}\right]_{\mathrm{o}}$ and $100 \mu \mathrm{M}\left[\mathrm{Ca}^{2+}\right]_{\mathrm{o}}$ (Figures 1D-F). The VDCC current density recorded at $+10 \mathrm{mV}$ $(-7.28 \pm 0.54 \mathrm{pA} / \mathrm{pF} ; n=11$ cells, seven animals $)$ was not significantly different compared to VDCC current density measured in $10 \mathrm{mM}\left[\mathrm{Ba}^{2+}\right]_{\mathrm{o}}$, alone (Figure 1C). However, the addition of $100 \mu \mathrm{M}\left[\mathrm{Ca}^{2+}\right]_{\mathrm{o}}$ dramatically influenced the efficacy of nifedipine to inhibit VDCC currents. As illustrated in Figure 1F, inward VDCC currents obtained in the combination of $10 \mathrm{mM}\left[\mathrm{Ba}^{2+}\right]_{0}$ and $100 \mu \mathrm{M}\left[\mathrm{Ca}^{2+}\right]_{0}$ were completely abolished by $1 \mu \mathrm{M}$ nifedipine. To further investigate the impact of $\left[\mathrm{Ca}^{2+}\right]_{0}$ on VDCC currents, single depolarizing voltage steps from a holding potential of -80 to $+10 \mathrm{mV}$ were used to elicit VDCC currents in the presence of increasing concentrations of nifedipine $\left(10^{-10}-10^{-6} \mathrm{M}\right)$ followed by drug washout (Figures $2 \mathrm{~A}-\mathbf{E}$ and Table 2). In $10 \mathrm{mM}\left[\mathrm{Ba}^{2+}\right]_{\mathrm{o}}$, nifedipine caused a concentration-dependent decrease in VDCC currents with an $\mathrm{IC}_{50}$ of $6.02 \pm 0.36 \mathrm{nM}(n=5$ cells from five animals) with $\sim 20 \%$ of the current insensitive to $1 \mu \mathrm{M}$ nifedipine. Addition of $100 \mu \mathrm{M}\left[\mathrm{Ca}^{2+}\right]_{\mathrm{o}}$ to the $10 \mathrm{mM}\left[\mathrm{Ba}^{2+}\right]_{\mathrm{o}}$ bath solution again facilitated the complete inhibition of VDCC currents by $1 \mu \mathrm{M}$ nifedipine, but did not change VDCC sensitivity to nifedipine ( $\mathrm{IC}_{50}$ value $5.12 \pm 0.41 \mathrm{nM} ; n=4$ cell from three animals). Upon washout of $1 \mu \mathrm{M}$ nifedipine, current density was not significantly different when compared to current density obtained prior to the start of the nifedipine concentration-response curve (Table 2). Current-voltage (I-V) plots shown in Figures 1C,F are consistent with the activation of high-voltage activated VDCCs, i.e., maximum current density was observed at $\sim+10 \mathrm{mV}$. To obtain higher resolution with respect to the voltage-dependent activation of VDCC currents, voltage ramp protocols were used that applied a continuous depolarization from a holding potential of -80 to $+50 \mathrm{mV}$ over the course of $300 \mathrm{~ms}$ (Figures 2D-F). This approach also enabled the study of the same cell using $10 \mathrm{mM}\left[\mathrm{Ba}^{2+}\right]_{\mathrm{o}}$ as the charge carrier in the presence and absence of $100 \mu \mathrm{M}$ $\left[\mathrm{Ca}^{2+}\right]_{0}$ (Figures 2D-F). No difference was detected in the membrane potential that evoked maximum VDCC currents in $10 \mathrm{mM}\left[\mathrm{Ba}^{2+}\right]_{\mathrm{o}}$ in the absence or presence of $100 \mu \mathrm{M}\left[\mathrm{Ca}^{2+}\right]_{\mathrm{o}}$ (9.99 \pm 0.08 vs. $10.01 \pm 0.08 \mathrm{mV} ; n=5$ cells from three animals; $p>0.05)$. Maximum VDCC current density in cells 

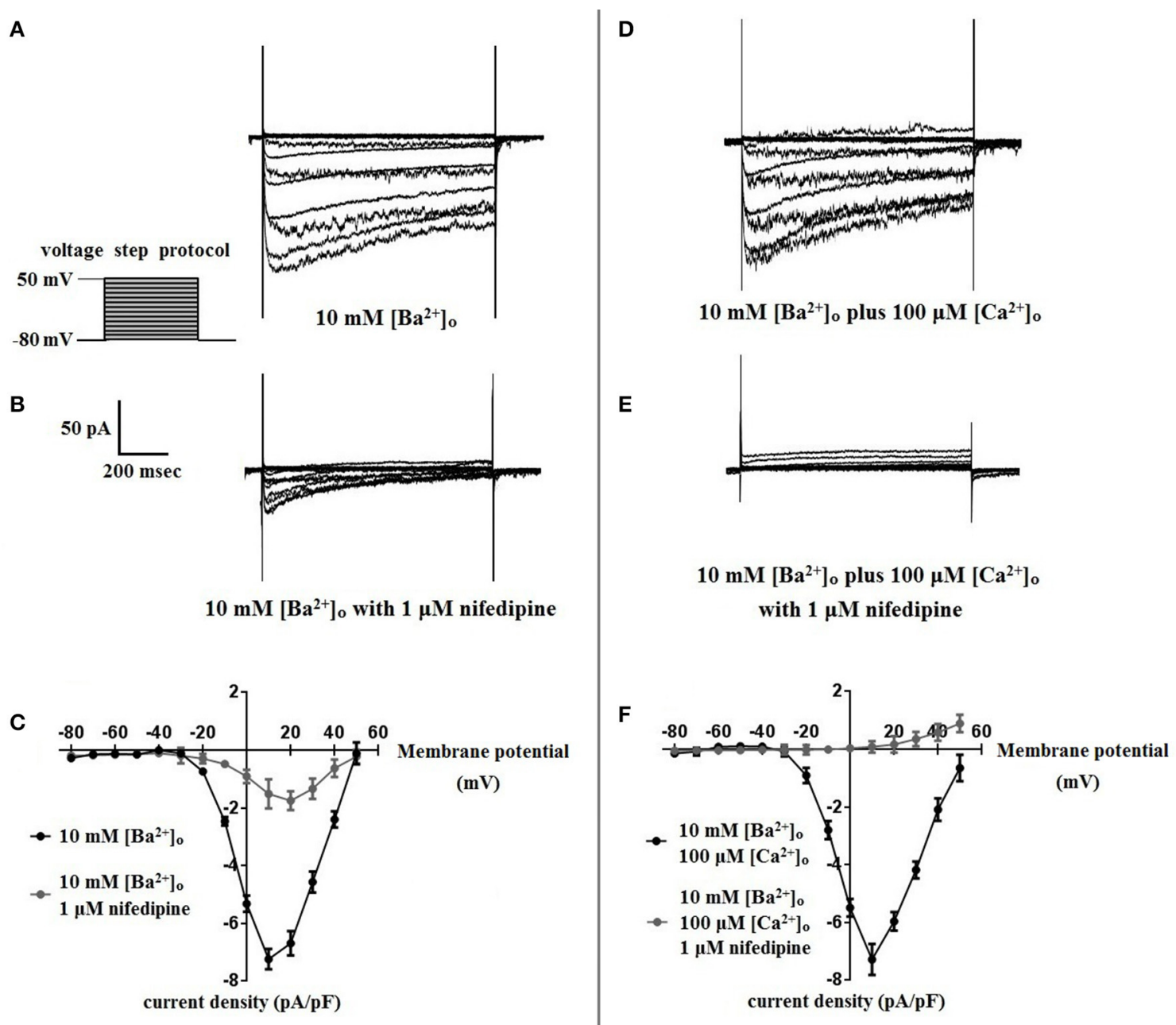

FIGURE 1 | Nifedipine inhibition of VDCC currents obtained in $10 \mathrm{mM}\left[\mathrm{Ba}^{2+}\right]_{0} \pm 100 \mu \mathrm{M}\left[\mathrm{Ca}^{2+}\right]_{0}$. VDCC currents were elicited in rat cerebral artery myocytes in response to successive $10 \mathrm{mV}$ depolarizing voltage steps from a holding potential of $-80 \mathrm{mV}$. (A,B) VDCC currents obtained using $\left.10 \mathrm{mM}^{\left[\mathrm{Ba}^{2+}\right.}\right]_{\mathrm{o}}$ as the charge

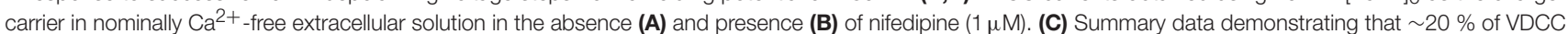
currents using $10 \mathrm{mM}\left[\mathrm{Ba}^{2+}\right]_{0}$ were not inhibited by $1 \mu \mathrm{M}$ nifedipine. (D,E) VDCC currents obtained using $10 \mathrm{mM}\left[\mathrm{Ba}^{2+}\right]_{0}$ plus $100 \mu \mathrm{M}\left[\mathrm{Ca}{ }^{2+}\right]_{0}$ in the absence (D) and presence $\mathbf{( E )}$ of nifedipine $(1 \mu \mathrm{M})$. (F) Summary data demonstrating that VDCC currents were completely inhibited by $1 \mu \mathrm{M}$ nifedipine in $\left.10 \mathrm{mM}^{\left[\mathrm{Ba}^{2+}\right.}\right]_{\mathrm{o}}$ plus $100 \mu \mathrm{M}\left[\mathrm{Ca}^{2+}\right]_{0}$.

bathed in $10 \mathrm{mM}\left[\mathrm{Ba}^{2+}\right]_{0}$ was also not significantly different in the absence or presence of $100 \mu \mathrm{M}\left[\mathrm{Ca}^{2+}\right]_{0}$ (Figures $2 \mathrm{G}-\mathrm{I}$ ). Voltages for half-maximal inactivation $\left(\mathrm{V}_{0.5 \text { inact }}\right)$ were $\sim-13.9$, -32.5 , and $-19.9 \mathrm{mV}$ in $10 \mathrm{mM}\left[\mathrm{Ba}^{2+}\right]_{\mathrm{o}}, 10 \mathrm{mM}\left[\mathrm{Ba}^{2+}\right]_{\mathrm{o}}+$ nifedipine $(1 \mu \mathrm{M})$ and $10 \mathrm{mM}\left[\mathrm{Ba}^{2+}\right]_{\mathrm{o}}+100 \mu \mathrm{M}\left[\mathrm{Ca}^{2+}\right]_{\mathrm{o}}$, respectively (Figures 3A-D and Table 1) Voltages for halfmaximal activation $\left(\mathrm{V}_{0.5 \mathrm{act}}\right)$ were similar in $10 \mathrm{mM}\left[\mathrm{Ba}^{2+}\right]_{\mathrm{o}}$ $\pm 100 \mu \mathrm{M}\left[\mathrm{Ca}^{2+}\right]_{0}$, but were shifted modestly $(\sim+8 \mathrm{mV})$ in $10 \mathrm{mM}\left[\mathrm{Ba}^{2+}\right]_{\mathrm{o}}$ plus $1 \mu \mathrm{M}$ nifedipine (Figure $3 \mathrm{E}$ and Table $\mathbf{1}$ ). In addition to 1,4-DHPs (e.g., nifedipine), L-type VDCCs are inhibited by benzothiazepines such as diltiazem. Figure 4 illustrates the concentration dependent inhibition by diltiazem of VDCC currents in $10 \mathrm{mM}\left[\mathrm{Ba}^{2+}\right]_{\mathrm{o}} \pm 100 \mu \mathrm{M}\left[\mathrm{Ca}^{2+}\right]_{\mathrm{o}}$. In contrast to the actions of nifedipine, diltiazem $(100 \mu \mathrm{M})$ caused complete inhibition of $10 \mathrm{mM}\left[\mathrm{Ba}^{2+}\right]_{0}$ VDCC currents irrespective of the presence or absence of $100 \mu \mathrm{M}\left[\mathrm{Ca}^{2+}\right]_{\mathrm{o}}$. Upon washout of $100 \mu \mathrm{M}$ diltiazam, current density was not significantly different when compared to a current density obtained prior to the start of the diltiazem concentrationresponse curve (Table 2).

\section{Nifedipine Inhibition of VDCC Currents Using $2 \mathrm{mM}\left[\mathrm{Ba}^{2+}\right]_{\circ}$ or $2 \mathrm{mM}\left[\mathrm{Ca}^{2+}\right]_{\circ}$ as a Charge Carrier}

Surface charges, influenced by the concentration of extracellular divalent cations can impact VDCC properties, including drug/ligand binding (Kass and Krafte, 1987). To examine the impact of divalent cation concentration on nifedipine inhibition, VDCC currents were recorded in cerebral artery myocytes in 


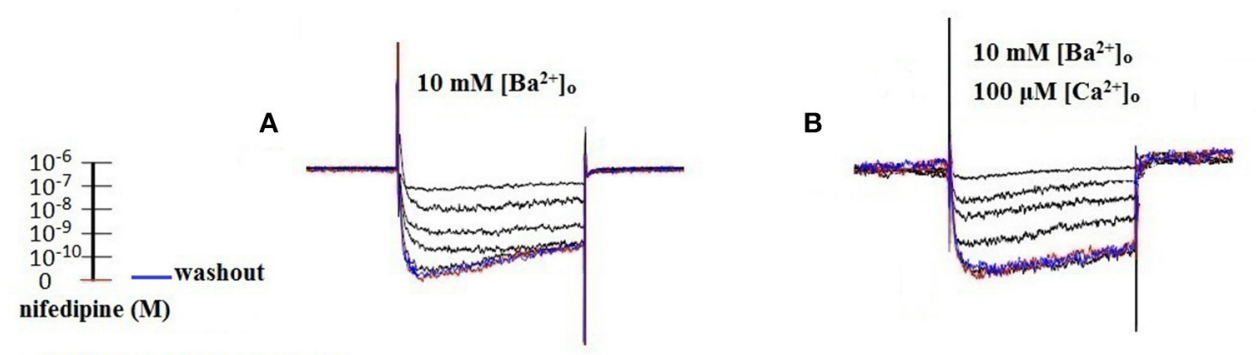

single step voltage protocol
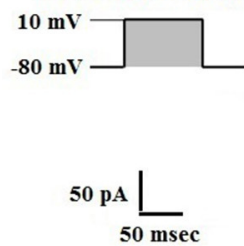

C

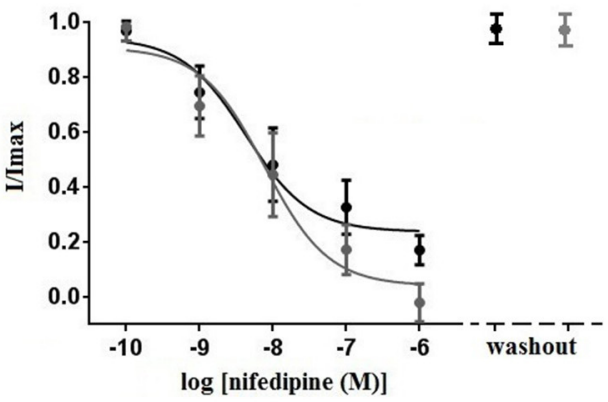

voltage ramp protocol

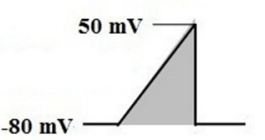

D
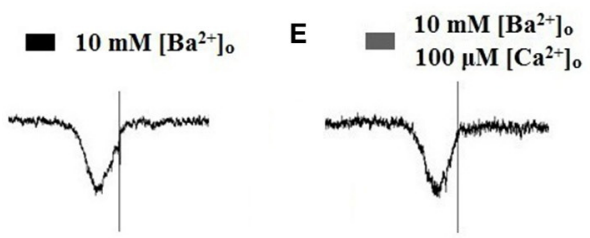

F

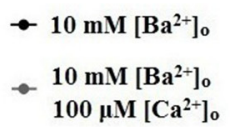

$50 \mathrm{pA} \bigsqcup_{50 \mathrm{msec}}$
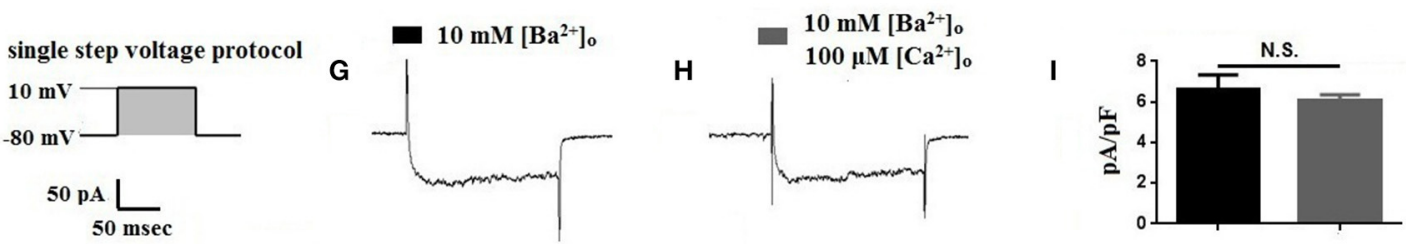

FIGURE 2 | Properties of VDCC currents obtained using $\mathbf{1 0} \mathbf{m M}\left[\mathbf{B a}^{\mathbf{2 +}}\right]_{\mathbf{o}} \pm \mathbf{1 0 0} \mu \mathbf{M}\left[\mathbf{C a}^{\mathbf{2}+}\right]_{0}$. (A-C) VDCC currents elicited by depolarizing voltage steps to $+10 \mathrm{mV}$ from a holding potential of $-80 \mathrm{mV}$. (A) Effect of increasing concentrations of nifedipine in $\left.10 \mathrm{mM}^{2} \mathrm{Ba}^{2+}\right]_{\mathrm{o}}$. (C) Effect of increasing concentrations of nifedipine in $10 \mathrm{mM}\left[\mathrm{Ba}^{2+}\right]_{0}$ plus $100 \mu \mathrm{M}\left[\mathrm{Ca}^{2+}\right]_{0}$. Traces in red represent currents obtained in cells prior to the addition of nifedipine. Traces in blue represent current traces obtained in cells following washout of $1 \mu \mathrm{M}$ nifedipine. (C) Concentration-inhibition curves of nifedipine on VDCC currents obtained in bath solution containing $10 \mathrm{mM}$ $\left[\mathrm{Ba}^{2+}\right]_{0} \pm 100 \mu \mathrm{M}\left[\mathrm{Ca}^{2+}\right]_{0}$. (D-F) VDCC currents evoked using a voltage ramp protocol that applied a continuous membrane potential depolarization from -80 to $+50 \mathrm{mV}$ over the course of $300 \mathrm{~ms}$. (D) VDCC currents from a cerebral artery myocyte in bath solution containing $10 \mathrm{mM}\left[\mathrm{Ba}^{2+}\right]_{0}$. (E) VDCC currents from the same cell depicted in (D) in bath solution containing $10 \mathrm{mM}\left[\mathrm{Ba}^{2+}\right]_{0}$ plus $100 \mu \mathrm{M}\left[\mathrm{Ca}^{2+}\right]_{0}$. (F) Summary data demonstrating that the membrane potential evoking maximum VDCC current density was not different in bath solution containing $10 \mathrm{mM}\left[\mathrm{Ba}^{2+}\right]_{0} \pm 100 \mu \mathrm{M}\left[\mathrm{Ca}^{2+}\right]_{0}$ (paired $t$-test, $\left.p>0.05\right)$. (G-I) VDCC currents evoked by voltage steps to $+10 \mathrm{mV}$ in cells in bath solution containing $10 \mathrm{mM}\left[\mathrm{Ba}^{2+}\right]_{0} \pm 100 \mu \mathrm{M}\left[\mathrm{Ca}^{2+}\right]_{0}$. Maximum current density at $+10 \mathrm{mV}$ was not different between groups (paired $t$-test, $p>0.05$ ).

$\mathrm{Ca}^{2+}$-free extracellular solution containing $2 \mathrm{mM}\left[\mathrm{Ba}^{2+}\right]_{\mathrm{o}}$ as a charge carrier (Figures 5A-C). As expected, maximum current density in $2 \mathrm{mM}\left[\mathrm{Ba}^{2+}\right]_{\mathrm{o}}(-3.77 \pm 0.37 \mathrm{pA} / \mathrm{pF}$ at $+10 \mathrm{mV}$; $n=13$ cells from eight animals) was decreased compared to VDCC current density obtained in $10 \mathrm{mM}\left[\mathrm{Ba}^{2+}\right]_{0}$. However, in contrast to currents obtained in $10 \mathrm{mM}\left[\mathrm{Ba}^{2+}\right]_{\mathrm{o}}$, VDCC currents were completely inhibited by $1 \mu \mathrm{M}$ nifedipine in $2 \mathrm{mM}\left[\mathrm{Ba}^{2+}\right]_{0}$. Similarly, VDCC currents were abolished by $1 \mu \mathrm{M}$ nifedipine when $2 \mathrm{mM}\left[\mathrm{Ca}^{2+}\right]_{0}$ was used in place of $2 \mathrm{mM}\left[\mathrm{Ba}^{2+}\right]_{0}$ as a charge carrier (Figures 5D-F). Nifedipine $\mathrm{IC}_{50}$ values in $2 \mathrm{mM}$
$\left[\mathrm{Ba}^{2+}\right]_{\mathrm{o}}$ were $1.85 \pm 0.29 \mathrm{nM}, n=5$ cells from two animals) and were $3.35 \pm 0.34 \mathrm{nM},(n=4$ cells from four animals, Figure 6$)$ in $2 \mathrm{mM}\left[\mathrm{Ca}^{2+}\right]_{\mathrm{o}}$. Diltiazem $\mathrm{IC}_{50}$ value of VDCC currents recorded in $2 \mathrm{mM}\left[\mathrm{Ba}^{2+}\right]_{\mathrm{o}}$ was $1.88 \pm 0.25 \mu \mathrm{M}, n=4$ from three animals. Upon washout of nifedipine and diltiazem, current density was not significantly different when compared to a current density obtained prior to drug application (Figure 6 and Table 2). Values obtained for $\mathrm{V}_{0.5 \mathrm{act}}$ and $\mathrm{V}_{0.5 \text { inact }}$ were similar between cells bathed in solution containing $2 \mathrm{mM}\left[\mathrm{Ba}^{2+}\right]_{\mathrm{o}}$ and $2 \mathrm{mM}\left[\mathrm{Ca}^{2+}\right]_{\mathrm{o}}$ (Table 1). 

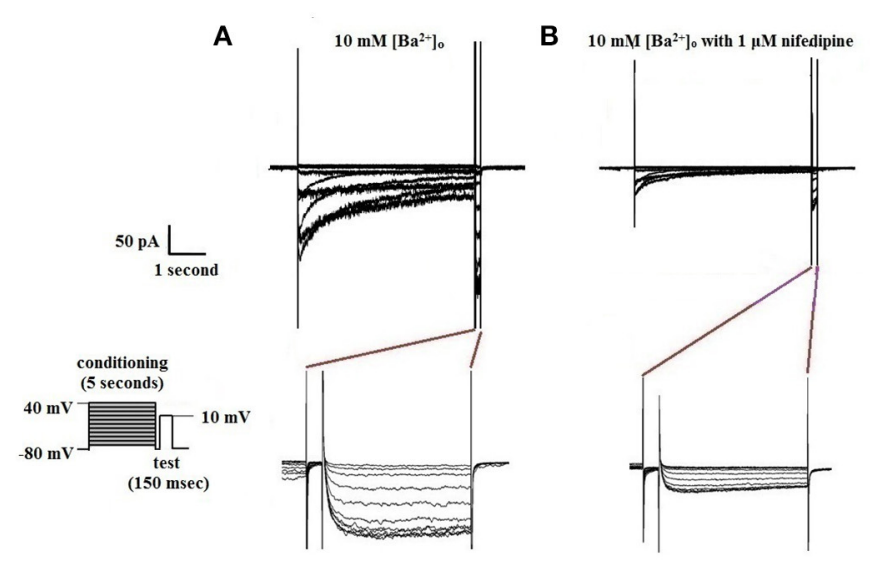

C $10 \mathrm{mM}\left[\mathrm{Ba}^{2+}\right]_{0}$ plus $100 \mu \mathrm{M}\left[\mathrm{Ca}^{2+}\right]_{0}$
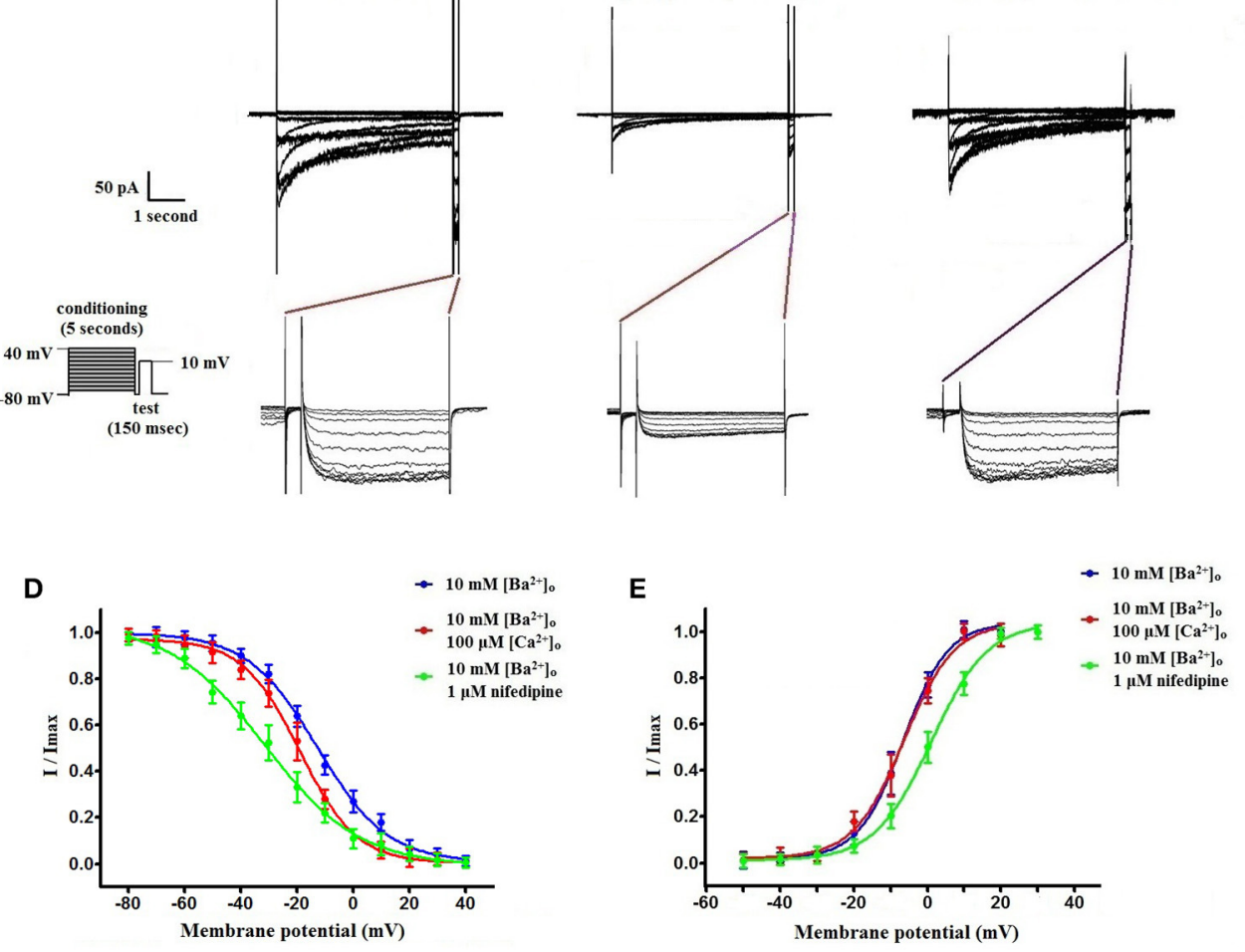

FIGURE 3 | Voltage-dependent inactivation and activation characteristics of VDCC currents recorded in $\left.10 \mathrm{mM}^{\left[\mathrm{Ba}^{2+}\right.}\right]_{\mathrm{o}} \pm 100 \mu \mathrm{M}\left[\mathrm{Ca}{ }^{2+}\right]_{\mathrm{o}}$. (A-C) Current recordings obtained from cells using a double-step voltage protocol that applied a $5 \mathrm{~s}$ conditioning pulse step to examine steady-state VDCC inactivation. Recordings obtained in extracellular solution containing $10 \mathrm{mM}\left[\mathrm{Ba}^{2+}\right]_{\mathrm{O}}$ (A), $10 \mathrm{mM}\left[\mathrm{Ba}^{2+}\right]_{0}$ with $1 \mu \mathrm{M}$ nifedipine (B), and $10 \mathrm{mM}\left[\mathrm{Ba}^{2+}\right]_{0}$ plus $100 \mu \mathrm{M}$ $\left[\mathrm{Ca}^{2+}\right]_{0}$ (C). (D) Steady-state inactivation curves obtained using the voltage protocol illustrated in (A-C). (E) VDCC activation curves derived from currents elicited by successive $10 \mathrm{mV}$ depolarizing voltage steps from a holding potential of $-80 \mathrm{mV}$.

TABLE 1 | VDCC current properties.

\begin{tabular}{|c|c|c|c|c|}
\hline Extracellular divalent cation & Voltage of half activation (mv) & Voltage of half inactivation (mv) & $\mathrm{IC}_{50}$ for nifedipine $(\mathrm{nm})$ & $\mathrm{IC}_{50}$ for diltiazem $(\mu \mathrm{m})$ \\
\hline $10 \mathrm{mM}\left[\mathrm{Ba}^{2+}\right]_{\mathrm{o}}$ with $1 \mu \mathrm{M}$ nifedipine & $1.51 \pm 0.96,(n=8)$ & $-32.46 \pm 1.05,(n=4)$ & & \\
\hline $2 \mathrm{mM}\left[\mathrm{Ba}^{2+}\right]_{\circ}$ & $-11.44 \pm 0.61,(n=13)$ & $-21.98 \pm 0.71,(n=8)$ & $1.85 \pm 0.29^{\mathrm{C}},(n=5)$ & \\
\hline $2 \mathrm{mM}\left[\mathrm{Ca}^{2+}\right]_{\mathrm{o}}$ & $-9.17 \pm 0.70,(n=10)$ & $-25.00 \pm 0.82,(n=7)$ & $3.35 \pm 0.34,(n=4)$ & \\
\hline
\end{tabular}

${ }^{a} p<0.05$ vs. $10 \mathrm{mM}\left[\mathrm{Ba}^{2+}\right]_{0}$ plus $100 \mu \mathrm{M}\left[\mathrm{Ca}^{2+}\right]_{0}$.

${ }^{b} p<0.05$ vs. $10 \mathrm{mM}\left[\mathrm{Ba}^{2+}\right]_{0}$ with $1 \mu \mathrm{M}$ nifedipine.

${ }^{c} p<0.05$ vs. $2 \mathrm{mM}\left[\mathrm{Ca}^{2+}\right]_{0}$.

\section{DISCUSSION}

This study demonstrates that the composition of extracellular divalent cations can profoundly alter the inhibition of wholecell VDCC currents by 1,4-DHPs such as nifedipine. Our data indicate that nifedipine inhibition of VDCC currents in rat cerebral artery myocytes can be influenced by two factors: (1) the presence or absence of $100 \mu \mathrm{M}\left[\mathrm{Ca}^{2+}\right]_{\mathrm{o}}$ when using $10 \mathrm{mM}$ $\left[\mathrm{Ba}^{2+}\right]_{\mathrm{o}}$ as a charge carrier- an effect likely mediated by the interaction of $\mathrm{Ca}^{2+}$ with an extracellular VDCC binding site and (2) the concentration of the extracellular divalent cation used as a charge carrier - an effect likely mediated by a change in surface charge. Further, these findings support the functional presence of a single population of high-voltage activated VDCCs in rat cerebral artery myocytes and demonstrate that the inhibition of these channels by nifedipine can be influence by the extracellular environment.

As depicted in Figure 1, nifedipine-resistant VDCC currents are absent when $100 \mu \mathrm{M} \mathrm{Ca}^{2+}$ is included in the extracellular solution during conventional whole-cell current recordings. This finding is consistent with a body of previous work indicating that the extracellular VDCC binding site for $\mathrm{Ca}^{2+}$ is coupled 


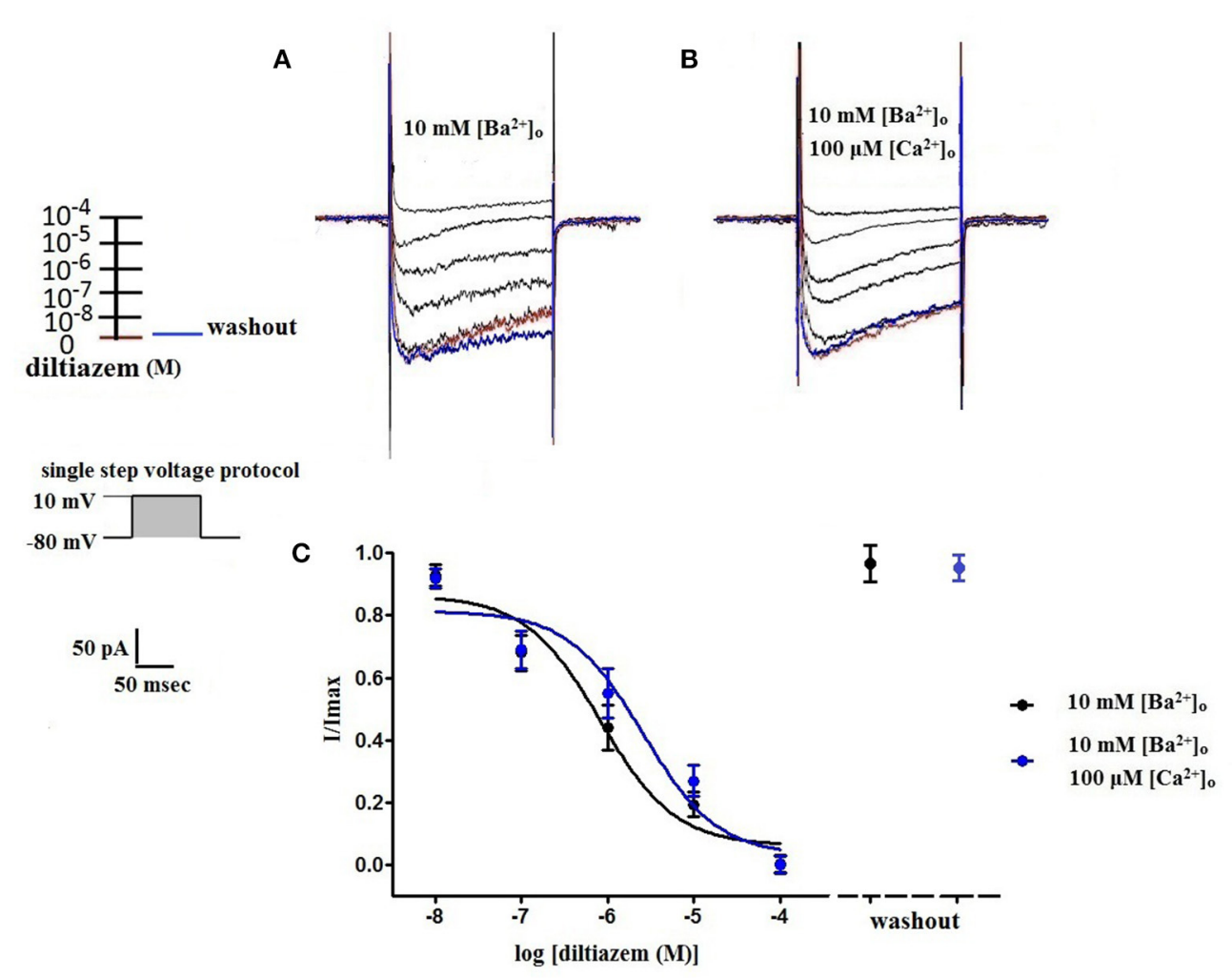

FIGURE 4 | Diltiazem abolishes VDCC currents in $10 \mathrm{mM}\left[\mathrm{Ba}^{2+}\right]_{0} \pm 100 \mu \mathrm{M}\left[\mathrm{Ca}^{2+}\right]_{0}$. VDCC currents elicited by depolarizing voltage steps to $+10 \mathrm{mV}$ from a holding potential of $-80 \mathrm{mV}$ in bath solutions containing $10 \mathrm{mM}\left[\mathrm{Ba}^{2+}\right]_{\mathrm{o}}$ (A) or $10 \mathrm{mM}\left[\mathrm{Ba}^{2+}\right]_{\mathrm{o}}$ plus $100 \mu \mathrm{M}\left[\mathrm{Ca}^{2+}\right]_{\mathrm{o}}$ (B). Traces in red represent currents obtained in cells prior to the addition of diltiazem. Traces in blue represent current traces obtained in cells following washout of $100 \mu \mathrm{M}$ diltiazem. (C) Concentration-inhibition curves of diltiazem on VDCC currents obtained in extracellular solution containing $10 \mathrm{mM}\left[\mathrm{Ba}^{2+}\right]_{\mathrm{o}} \pm 100 \mu \mathrm{M}\left[\mathrm{Ca}^{2+}\right]_{\mathrm{o}}$.

TABLE 2 | VDCC current density \pm nifedipine or diltiazem.

\begin{tabular}{|c|c|c|c|c|c|c|}
\hline & \multicolumn{3}{|c|}{ VDCC current density (pA/pF) } & \multicolumn{3}{|c|}{ VDCC current density $(\mathrm{pA} / \mathrm{pF})$} \\
\hline $10 \mathrm{mM}\left[\mathrm{Ba}^{2+}\right]_{\mathrm{O}}$ & $-7.35 \pm 0.57^{\#}$ & $-1.42 \pm 0.58$ & $-7.01 \pm 0.65$ & $-7.13 \pm 0.59^{\#}$ & $-0.09 \pm 0.18$ & $-6.93 \pm 0.58$ \\
\hline $10 \mathrm{mM}\left[\mathrm{Ba}^{2+}\right]_{\circ}$ plus $100 \mu \mathrm{M}\left[\mathrm{Ca}^{2+}\right]_{\circ}$ & $-7.29 \pm 0.66^{\#}$ & $-0.13 \pm 0.70$ & $-6.95 \pm 0.67$ & $-6.94 \pm 0.52^{\#}$ & $-0.16 \pm 0.15$ & $-6.90 \pm 0.44$ \\
\hline $2 \mathrm{mM}\left[\mathrm{Ba}^{2+}\right]_{\circ}$ & $-3.52 \pm 0.33^{\#}$ & $-0.17 \pm 0.15$ & $-3.36 \pm 0.30$ & $-3.37 \pm 0.38^{\#}$ & $-0.07 \pm 0.09$ & $-3.43 \pm 0.41$ \\
\hline
\end{tabular}

${ }^{\#}$ not significantly different compared to after drug washout $(p>0.05)$.

to a 1,4-DHP binding site on the channel and that $\left[\mathrm{Ca}^{2+}\right]_{0}$ is required for high affinity 1,4-DHP binding (Ebata et al., 1990; Knaus et al., 1992; Nakajima et al., 2002). Further, a $\mathrm{K}_{0.5}$ of $300 \mathrm{nM}$ for $\left[\mathrm{Ca}^{2+}\right]_{0}$ to stabilize the high affinity binding domain for 1,4-DHPs was reported in L-type VDCC purified from rabbit skeletal muscle (Staudinger et al., 1991). In our study, the addition of $100 \mu \mathrm{M}\left[\mathrm{Ca}^{2+}\right]_{0}$ enabled the complete inhibition of VDCC currents by $1 \mu \mathrm{M}$ nifedipine, but did not change VDCC sensitivity to nifedipine, with $\mathrm{IC}_{50}$ values similar $\pm\left[\mathrm{Ca}^{2+}\right]_{\mathrm{o}}$ (Figure 2). This observation is consistent with the work of Yamada et al. that reported a reduction in the maximum number of high affinity 1,4-DHP binding sites either in the presence of $\left[\mathrm{Ba}^{2+}\right]_{0}$ or the absence of $\left[\mathrm{Ca}^{2+}\right]_{0}$ in porcine coronary artery preparations (Yamada et al., 1990). In addition to 1,4-DHPs, L-type VDCCs are selectively inhibited by two other classes of compounds, benzothiazepines, and phenylalkylamines, with each class of inhibitors having distinct binding sites to the VDCC alphal subunit (Hille, 2001). We found the efficacy of the benzothiazepine, diltiazem, to be independent of $\left[\mathrm{Ca}^{2+}\right]_{\mathrm{o}}$. In effect, diltiazem $(100 \mu \mathrm{M})$ completely abolished $10 \mathrm{mM}\left[\mathrm{Ba}^{2+}\right]_{\mathrm{o}}$ VDCC currents irrespective of the presence or absence of $\left[\mathrm{Ca}^{2+}\right]_{\mathrm{o}}$ (Figure 4), consistent with the existence of 


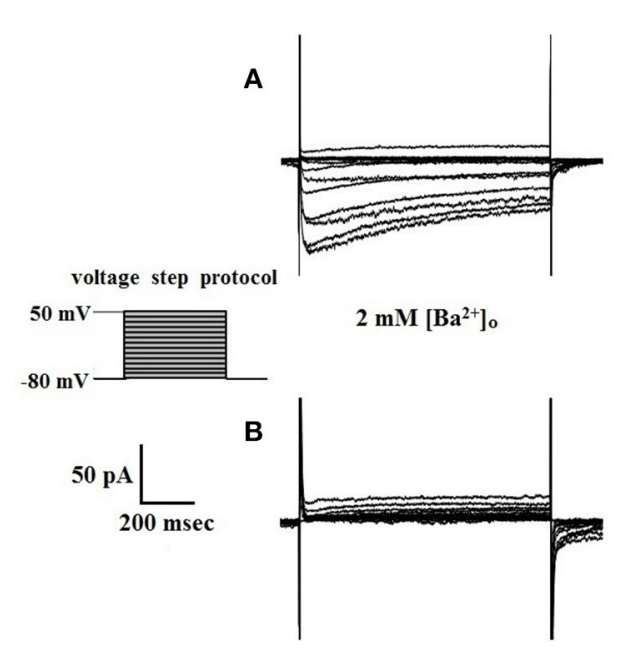

$2 \mathrm{mM}\left[\mathrm{Ba}^{2+}\right]_{o}$ with $1 \mu \mathrm{M}$ nifedipine

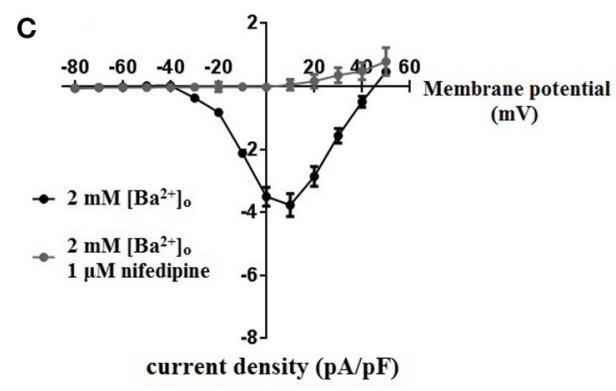

D

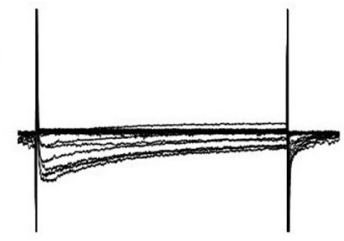

$2 \mathrm{mM}\left[\mathrm{Ca}^{2+}\right]_{\mathrm{o}}$

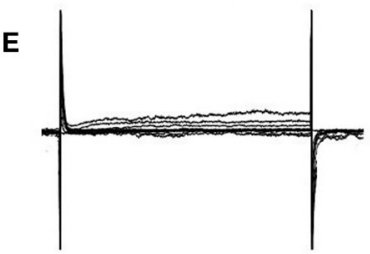

$2 \mathrm{mM}\left[\mathrm{Ca}^{2+}\right]_{o}$ with $1 \mu \mathrm{M}$ nifedipine

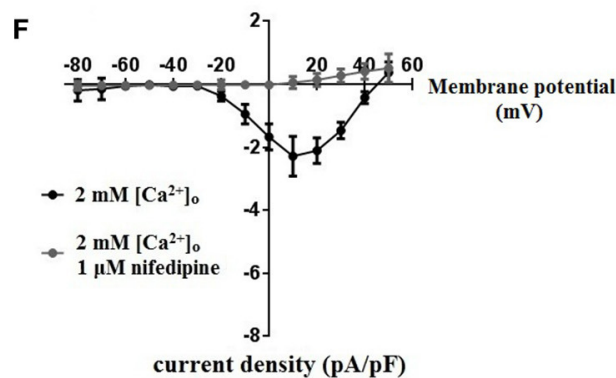

FIGURE $\mathbf{5}$ | Nifedipine inhibition of VDCC currents obtained in $\mathbf{2} \mathbf{~ m M}\left[\mathbf{B a}^{\mathbf{2 +}}\right]_{0}$ or $\mathbf{2} \mathbf{~ m M ~}\left[\mathbf{C a}^{\mathbf{2 +}}\right]_{0}$. VDCC currents were elicited in rat cerebral artery myocytes in response to successive $10 \mathrm{mV}$ depolarizing voltage steps from a holding potential of $-80 \mathrm{mV}$. (A,B) VDCC currents obtained using $2 \mathrm{mM}\left[\mathrm{Ba}^{2+}\right]_{0}$ as the charge carrier in nominally $\mathrm{Ca}^{2+}$-free extracellular solution in the absence $\mathbf{( A )}$ and presence $\mathbf{( B )}$ of nifedipine $(1 \mu \mathrm{M})$. (C) Summary data demonstrating that VDCCs currents were

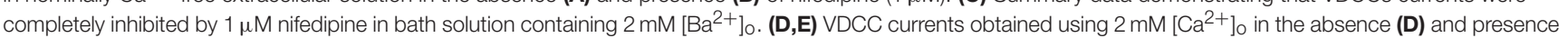
(E) of nifedipine $(1 \mu \mathrm{M})$. (F) Summary data demonstrating that VDCC currents were completely inhibited by $1 \mu \mathrm{M}$ nifedipine in bath solution containing $2 \mathrm{mM}\left[\mathrm{Ca}{ }^{2+}\right]_{0}$.

independent binding sites for 1,4-DHPs and benzothiazepines. This observation supports the work of other groups that have shown that L-type VDCC mutations that prevent 1,4-DHP binding do not alter channel inhibition by diltiazem (Yamaguchi et al., 2000; Walsh et al., 2007).

Our data indicate that surface charge, influenced by the concentration of extracellular divalent cations, can also affect inhibition of L-type VDCCs by nifedipine. As shown in Figures 5, 6, decreasing the extracellular concentration of $\mathrm{Ba}^{2+}$ from 10 to $2 \mathrm{mM}$ dramatically increased VDCC inhibition by nifedipine. In this case, the change in nifedipine efficacy was independent of $\left[\mathrm{Ca}^{2+}\right]_{0}$, as the experimental series was done in nominally $\mathrm{Ca}^{2+}$-free extracellular solution. These findings are remarkably similar to those reported by Kass and Krafte examining nisoldipine block of L-type VDCC in cardiac myocytes (Kass and Krafte, 1987). These investigators provided evidence that a depolarizing shift in surface charge and the resulting impact on channel gating was largely responsible for the apparent antagonism between divalent cations and 1,4DHPs. In our present study, $\mathrm{V}_{0.5 a c t}$ was shifted positively from -22.0 to $-13.5 \mathrm{mV}$ when $2 \mathrm{mM}\left[\mathrm{Ba}^{2+}\right]_{0}$ was replaced with $10 \mathrm{mM}\left[\mathrm{Ba}^{2+}\right]_{\mathrm{o}}$, indicative of a depolarizing shift in surface charge. However, additional mechanisms independent of the effects of surface charge on VDCC gating such as direct interaction of divalent cations with the 1,4-DHP binding site may also contribute to nifedipine-resistant currents observed in the presence of higher concentrations of divalent cations.

Our data are consistent with the presence of highvoltage activated L-type VDCCs in cerebral artery myocytes (Figures 1, 2, 5). Under physiological conditions, i.e., $2 \mathrm{mM}$ $\left[\mathrm{Ca}^{2+}\right]_{0}, 1,4$-DHPs would be predicted to inhibit these channels, as has been shown in a number of functional studies (Knot and Nelson, 1998; Gokina and Osol, 2002; Wellman et al., 2002; Ishiguro et al., 2005; Syyong et al., 2009). Interestingly, other studies using a combination of ex vivo diameter measurements, molecular biology, western blotting, and electrophysiology indicate the co-existence of nifedipine-insensitive low-voltage activated T-type VDCCs (Cav3.x family members) along with L-type VDCCs in cerebral artery myocytes (Kuo et al., 2010; Abd 


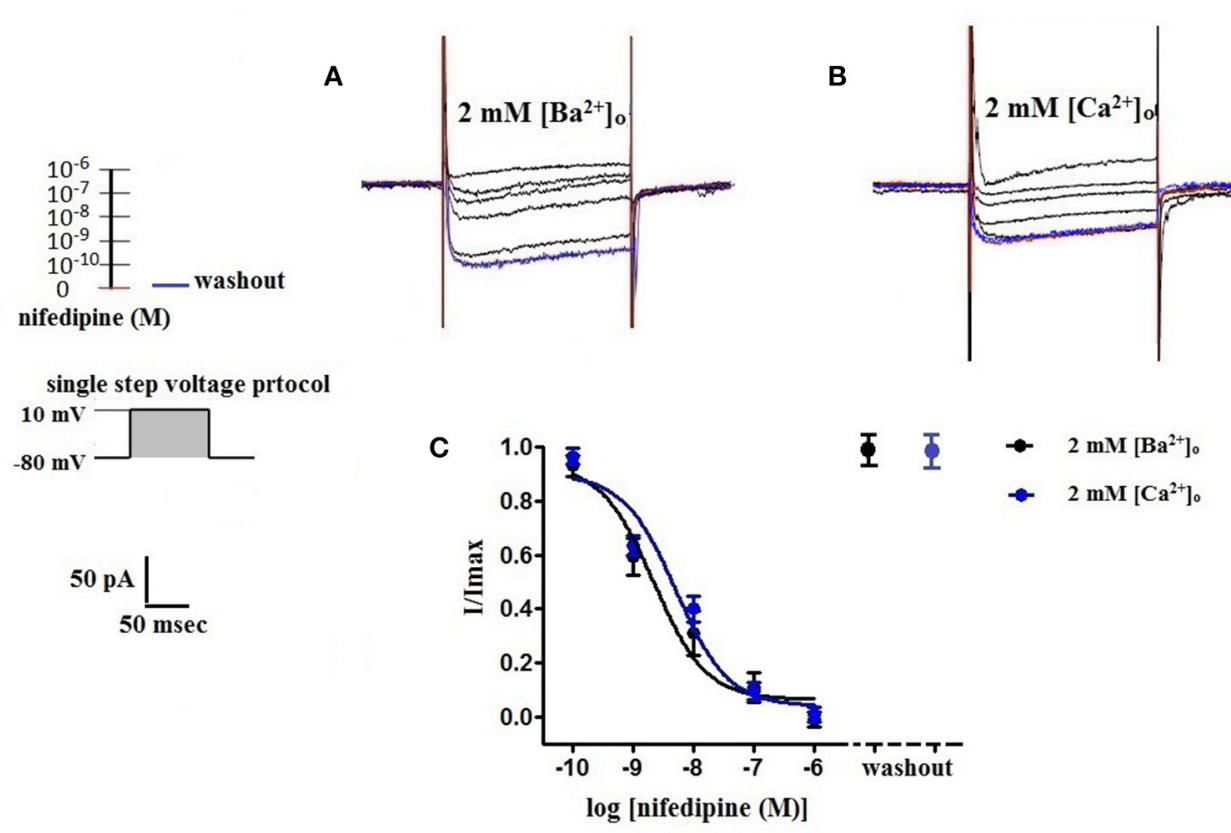

FIGURE 6 | Concentration-dependent inhibition of VDCC currents by nifedipine in $2 \mathrm{mM}\left[\mathrm{Ba}^{2+}\right]_{\mathrm{o}}$ or $2 \mathrm{mM}\left[\mathrm{Ca}^{2+}\right]_{\mathrm{o}}$. VDCC currents elicited by depolarizing voltage steps to $+10 \mathrm{mV}$ from a holding potential of $-80 \mathrm{mV}$. (A) Effect of increasing concentrations of nifedipine in bath solution containing $2 \mathrm{mM}\left[\mathrm{Ba}^{2+}\right]_{\mathrm{o}}$. (B) $\mathrm{Effect}$ of increasing concentrations of nifedipine in bath solution containing $2 \mathrm{mM}\left[\mathrm{Ca}^{2+}\right]_{\mathrm{o}}$. Traces in red represent currents obtained in cells prior to the addition of nifedipine. Traces in blue represent current traces obtained in cells following washout of $1 \mu \mathrm{M}$ nifedipine. (C) Concentration-inhibition curves of nifedipine on VDCC currents obtained in bath solution containing either $2 \mathrm{mM}\left[\mathrm{Ba}^{2+}\right]_{0}$ or $2 \mathrm{mM}\left[\mathrm{Ca}^{2+}\right]_{\mathrm{o}}$.

El-Rahman et al., 2013; Harraz and Welsh, 2013b; Harraz et al., 2015). In the current study, the current- voltage relationships that were obtained are consistent with those of high-voltage activated VDCCs, rather than with properties characteristic of those reported for T-type VDCCs (Lambert et al., 2014). Further, the modest depolarizing shift in the current-voltage relationship of nifedipine-resistant currents obtained in $10 \mathrm{mM}$ $\mathrm{Ba}^{2+}$ is also not consistent with the presence of T-type channels. Presently, the reason why T-type VDCC currents were detected in the above-mentioned studies, but not in our study is unclear.

In conclusion, this study demonstrates that the composition of extracellular divalent cations can profoundly impact the binding of 1,4-DHPs to L-type VDCCs. These findings suggest that measurements of VDCC currents should be preferentially carried out in physiological concentrations of divalent cations.

\section{REFERENCES}

Abd El-Rahman, R. R., Harraz, O. F., Brett, S. E., Anfinogenova, Y., Mufti, R. E., Goldman, D., et al. (2013). Identification of L- and T-type $\mathrm{Ca}^{2+}$ channels in rat cerebral arteries: role in myogenic tone development. Am. J. Physiol. Heart Circ. Physiol. 304, H58-H71. doi: 10.1152/ajpheart.00476.2012

Alexander, S. P. H., Catterall, W. A., Kelly, E., Marrion, N., Peters, J. A., Benson, H. E., et al. (2015). The concise guide to PHARMACOLOGY 2015/16: voltagegated ion channels. Br. J. Pharmacol. 172, 5904-5941. doi: 10.1111/bph.13349

\section{AUTHOR CONTRIBUTIONS}

FW contributed to data acquisition, data analysis, and manuscript preparation. MK contributed to data interpretation and manuscript revision. GW contributed to study design, data analysis/interpretation, and manuscript preparation.

\section{FUNDING}

This study was supported by the Totman Medical Research Trust, Grants from National Institutes of Health (No. P01-HL2095488, P20-RR-16435, and R01-HL-078983), the American Heart Association (14SDG20150027), the Peter Martin Fund, the National Natural Science Foundation of China (No. 81260182, 81560206) and the Natural Science Foundation of Yunnan Province (No. FB2016121). 
Gokina, N. I., and Osol, G. (2002). Actin cytoskeletal modulation of pressureinduced depolarization and $\mathrm{Ca}^{2+}$ influx in cerebral arteries. Am. J. Physiol. Heart Circ. Physiol. 282, H1410-H1420. doi: 10.1152/ajpheart.00441.2001

Harraz, O. F., Visser, F., Brett, S. E., Goldman, D., Zechariah, A., Hashad, A. M., et al. (2015). Cav 1.2/Cav3.x channels mediate divergent vasomotor responses in human cerebral arteries. J. Gen. Physiol. 145, 405-418. doi: $10.1085 /$ jgp. 201511361

Harraz, O. F., and Welsh, D. G. (2013a). Protein kinase A regulation of T-type $\mathrm{Ca}^{2+}$ channels in rat cerebral arterial smooth muscle. J. Cell. Sci. 126, 2944-2954. doi: $10.1242 /$ jcs. 128363

Harraz, O. F., and Welsh, D. G. (2013b). T-type $\mathrm{Ca}^{2+}$ channels in cerebral arteries: approaches, hypotheses, and speculation. Microcirculation 20, 299-306. doi: $10.1111 /$ micc. 12038

Hille, B. (2001). Ion Channels of Excitable Membranes. Sunderland, MA: Sinauer Associates, Inc. Publishers, 100-108.

Ishiguro, M., Wellman, T. L., Honda, A., Russell, S. R., Tranmer, B. I., and Wellman, G. C. (2005). Emergence of a R-type $\mathrm{Ca}^{2+}$ channel (Cav2.3) contributes to cerebral artery constriction after subarachnoid hemorrhage. Circ. Res. 96, 419-426. doi: 10.1161/01.RES.0000157670.49936.da

Kass, R. S., and Krafte, D. S. (1987). Negative surface charge density near heart calcium channels. Relevance to block by dihydropyridines. J. Gen. Physiol. 89, 629-644. doi: 10.1085/jgp.89.4.629

Knaus, H. G., Moshammer, T., Kang, H. C., Haugland, R. P., and Glossmann, H. (1992). A unique fluorescent phenylalkylamine probe for L-type $\mathrm{Ca}^{2+}$ channels. Coupling of phenylalkylamine receptors to $\mathrm{Ca}^{2+}$ and dihydropyridine binding sites. J. Biol. Chem. 267, 2179-2189.

Knot, H. J., and Nelson, M. T. (1998). Regulation of arterial diameter and wall $\left[\mathrm{Ca}^{2+}\right]$ in cerebral arteries of rat by membrane potential and intravascular pressure. J. Physiol. 508, 199-209. doi: 10.1111/j.1469-7793.1998. 199br.x

Koide, M., Penar, P. L., Tranmer, B. I., and Wellman, G. C. (2007). Heparin-binding EGF-like growth factor mediates oxyhemoglobin-induced suppression of voltage-dependent potassium channels in rabbit cerebral artery myocytes. Am. J. Physiol. Heart Circ. Physiol. 293, H1750-H1759. doi: 10.1152/ajpheart.00443.2007

Kuo, I. Y., Ellis, A., Seymour, V. A., Sandow, S. L., and Hill, C. E. (2010). Dihydropyridine-insensitive calcium currents contribute to function of small cerebral arteries. J. Cereb. Blood Flow Metab. 30, 1226-1239. doi: $10.1038 / \mathrm{jcbfm} .2010 .11$

Lambert, R. C., Bessaih, T., Crunelli, V., and Leresche, N. (2014). The many faces of T-type calcium channels. Pflugers Arch. 466, 415-423. doi: 10.1007/s00424-013-1353-6

Moosmang, S., Schulla, V., Welling, A., Feil, R., Feil, S., Wegener, J. W., et al. (2003). Dominant role of smooth muscle L-type calcium channel Cav1.2 for blood pressure regulation. EMBO J. 22, 6027-6034. doi: 10.1093/emboj/ cdg583

Nakajima, M., Yamada, S., Uchida, S., and Kimura, R. (2002). In vivo measurement of 1,4-dihydropyridine receptors in mesenteric arteries of spontaneously hypertensive rats and effect of nifedipine and cilnidipine. Biol. Pharm. Bull. 25, 24-28. doi: 10.1248/bpb.25.24
Nikitina, E., Zhang, Z. D., Kawashima, A., Jahromi, B. S., Bouryi, V. A., Takahashi, M., et al. (2007). Voltage-dependent calcium channels of dog basilar artery. J. Physiol. 580, 523-541. doi: 10.1113/jphysiol.2006.126128

Nystoriak, M. A., Murakami, K., Penar, P. L., and Wellman, G. C. (2009). $\mathrm{Ca}_{V} 1.2$ splice variant with exon $9^{*}$ is critical for regulation of cerebral artery diameter. Am. J. Physiol. Heart Circ. Physiol. 297, H1820-H1828. doi: 10.1152/ajpheart.00326.2009

Nystoriak, M. A., O’Connor, K. P., Sonkusare, S. K., Brayden, J. E., Nelson, M. T., and Wellman, G. C. (2011). Fundamental increase in pressure-dependent constriction of brain parenchymal arterioles from subarachnoid hemorrhage model rats due to membrane depolarization. Am. J. Physiol. Heart Circ. Physiol. 300, H803-H812. doi: 10.1152/ajpheart.00760.2010

Staudinger, R., Knaus, H. G., and Glossmann, H. (1991). Positive heterotropic allosteric regulators of dihydropyridine binding increase the $\mathrm{Ca}^{2+}$ affinity of the L-type $\mathrm{Ca}^{2+}$ channel. Stereoselective reversal by the novel $\mathrm{Ca}^{2+}$ antagonist BM 20.1140. J. Biol. Chem. 266, 10787-10795.

Syyong, H. T., Yang, H. H., Trinh, G., Cheung, C., Kuo, K. H., and van Breemen, C. (2009). Mechanism of asynchronous $\mathrm{Ca}^{2+}$ waves underlying agonistinduced contraction in the rat basilar artery. Br. J. Pharmacol. 156, 587-600. doi: 10.1111/j.1476-5381.2008.00063.x

Walsh, K. B., Zhang, J., Fuseler, J. W., Hilliard, N., and Hockerman, G. H. (2007). Adenoviral-mediated expression of dihydropyridine-insensitive L-type calcium channels in cardiac ventricular myocytes and fibroblasts. Eur. J. Pharmacol. 565, 7-16. doi: 10.1016/j.ejphar.2007.02.049

Wellman, G. C. (2006). Ion channels and calcium signaling in cerebral arteries following subarachnoid hemorrhage. Neurol. Res. 28, 690-702. doi: 10.1179/016164106X151972

Wellman, G. C., Nathan, D. J., Saundry, C. M., Perez, G., Bonev, A. D., Penar, P. L., et al. (2002). $\mathrm{Ca}^{2+}$ sparks and their function in human cerebral arteries. Stroke 33, 802-808. doi: 10.1161/hs0302.104089

Yamada, S., Kimura, R., Harada, Y., and Nakayama, K. (1990). Calcium channel receptor sites for $(+)-\left[{ }^{3} \mathrm{H}\right] \mathrm{PN} 200-110$ in coronary artery. J. Pharmacol. Exp. Ther. 252, 327-332.

Yamaguchi, S., Okamura, Y., Nagao, T., and Adachi-Akahane, S. (2000). Serine residue in the IIIS5-S6 linker of the L-type $\mathrm{Ca}^{2+}$ channel alpha $1 \mathrm{C}$ subunit is the critical determinant of the action of dihydropyridine $\mathrm{Ca}^{2+}$ channel agonists. J. Biol. Chem. 275, 41504-41511. doi: 10.1074/jbc.M007165200

Young, A. M., Karri, S. K., Helmy, A., Budohoski, K. P., Kirollos, R. W., Bulters, D. O., et al. (2015). Pharmacologic management of subarachnoid hemorrhage. World Neurosurg. 84, 28-35. doi: 10.1016/j.wneu.2015.02.004

Conflict of Interest Statement: The authors declare that the research was conducted in the absence of any commercial or financial relationships that could be construed as a potential conflict of interest.

Copyright (c) 2017 Wang, Koide and Wellman. This is an open-access article distributed under the terms of the Creative Commons Attribution License (CC BY). The use, distribution or reproduction in other forums is permitted, provided the original author(s) or licensor are credited and that the original publication in this journal is cited, in accordance with accepted academic practice. No use, distribution or reproduction is permitted which does not comply with these terms. 